ついて述べた．また，京大整形外科・長井淳博 士は, Charnley 型人工股関節手術の利点とし て, 1. 直径の小さい人工骨頭と HDP ソケット の組み合せは，マサッが小さく，長期間人工関 節の弛緩を生じない．2. 完全な無菌手術操作の 採用，3. 大転子を外方移動することにより，股 関節の免荷を得ることができ，その結果，耐久 性を増すことができる. 4. 手術器具の完備につ いて説明し，Charnley 型が最も優秀であるこ とを主張した. 神戸大学・柏木大治教授は, 日 本人に多い先天性股関節脱臼に続発した変形性 股関節症に対して, 変形ソケットを考案し, 力 学的実験を行なった.この変形ソケットに関し， 筆者等は，人工関節のソケット弛緩は，骨盤と 骨セメント間におこるのであるから，変形ソケ ットの使用は解決にならず，人工関節手術と日 蓋形成術の併用が必要であると主張してきてい る. 東京医歯大 - 古屋光太郎助教授は, Socket Cup 人工股関節手術において， Cup 内の大腿 骨々頭の壊死の例を提示した。 また，新しい骨 セメント MMA-TBB を開発し, 従来の骨セメ ントに比し, 生体反応が少なく, 弾力性も骨盤 に近く，臨床的に使用可能であると報告した．
九州大学・西尾篤人教授は，青年の変形性股関 節症に対し骨セメントを用いない Socket-Cup 人工股関節手術を開発し，臨床成績について述 べた．慈恵医大・赤松功也助教授は，骨セメント を用いない人工股関節を開発し，動物実験と臨 休成績について述べた。岡山大学・児玉俊夫教 授，山本純己助手は，独自に開発した人工膝関 節の各種について解剖学的, 運動力学的特長に ついて詳述した. 信州大学・寺山和雄助教授は Geometric 人工膝関節の臨床成績について述べ, この人工膝関節と生体膝関節の運動力学上の差 異について検討し報告した. 最後に順天堂大・ 山内裕雄助教授は，人工指関節の歷史的発展過 程と, 生体力学上の諸条件, 臨床成績について 述べた.

以上の発表に対し，会場より，敷田草治氏， 赤星義彦教授, 田川宏助教授, 嶋良宗教授, 田 中清介講師, 山田憲吾教授，木下勇講師による 発言があり，活発な討論が行なわれた。しかし， 時間の制限があり，十分意をつくせなかった感 があった. 今後この分野の研究の発展を期待し, 臨床成績の一層の向上を望みたいと思う。

\title{
“八リ麻酔”印象記
}

国立病院医療センター

$$
\text { 山下 九 }
$$

司 会 東京医科歯科大学医学部・池園悦太郎

演 者 日産厚生会玉川病院 - 代田 文彦, 都立豊島病院・飛松 源治, 東京逓信病院・許 瑞光, 大阪医科大学・政山 功一, 岡山大学医学部・倉林 譲, 昭和大学医学部・武重 千冬

発言者 がま産婦人科・蛂崎 要, 関東労㷋病院・久場 襄, 国立高崎病院・福島 和昭

新潟大学医学部・下地 恒毅, 京都疼病研究所・永山 薰造, 東京医科歯科大学医学部・沢 桓, 松本＼cjkstart勲, 北里大学衛生学部・相川 貞男, 日本大学駿河台病院・鈴木 太

針マスイは1958年中国で始めて扇桃摘出に用 いられ,その総数は40～50万, 成功率は70 96\% といわれている. 第19回日本医学会総会で紹介 された針マスイの例数は，耳鼻科232例（代田）, 産婦人科46例(飛松), および 108 例(蠇崎), 脳 神経外科91例（許）および歯科 308 例（福島） で，その成功率は福島の63\%を除き $80 \%$ 以上を 示している.

その問題点は，いわゆる三関（皮膚痛覚麻痺

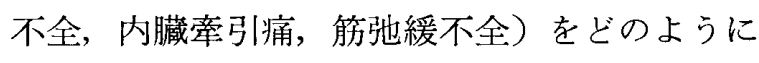
して対処するか，取穴はどのようにするか，通 電の方法をどのようにするか，その適応と将来 はどう考えたらよいか，そしてその効果機序は 果たしてどのように考えられるかなどの諸点で ある。

皮膚切開に際する疼痛に対しては局所にキシ ロカイゼリーを塗布したり，患者の涾吸気時に 一挙にメスを入れたり，それぞれ工夫をしてい 
る.内蔵铑引痛には, 耳の肺点を用いたり, 硬 膜外麻酔の併用 (鈴木) キシロカイン液の腹腔 内撒布なども行なわれている. 笳弛緩に対して は耳針の併用も余り効果はない。

取穴については，遠隔部の経穴を用いるか， 手術局所近くの末梢神経部を神経ブロック様式 (久場）を用いるか，あるいは古典にのっとっ た取穴を行なう（永山）など種々の意見がある. ハーディ疼痛計の改良型の中浜氏式疼痛計を 用いて，手術局所の疼痛閾值を計測して，取穴 部位を決定する方法（政山）も考えられるが， この疼痛計では皮膚表面の疼痛閾值しか測定で きず，深部感覚の指標にならないとの批判も行 なわれた．皮膚・深部感覚ともに測定可能な疼 痛間值の測定方法の研究は将来の問題であろう。

通電の方法は，針対プレートは深部に，針対 針は皮虔に除痛効果があるらしいとの発言もあ ったが, 受ける方の受容度が問題とされ，通電 方法では大差がないらしいの結論であった。

しかし筋の収縮をきたす方が，針マスイ効果 を示す脳波の出現が多いとする動物実験（武重） からすると，マスイ時の筋の攣縮もある意味を もっていそうな気もする。

針マスイ時に用いる補助剂については前投薬 を用いることは必ずしも必要ではなく，ドロレ プタンやオピスタンはかえって効果を悪くする との発言 (福島) もあった。

効果機序について大切なつぼの問題に関して は，犬，猫，鬼，ラッテ，マウスに「ノイロメ 一タ」を用いて定めた反応良導点は $100 \%$ に近 く末梢神経が見られる（倉林）との意見に対し，
人では経穴と思われる部位と他の部では全く同 様な組織所見であった（松本）との見解が対立 した。

マスイ効果がどうして起こるかについて，動 物の深部脳波では，マスイの経過とともに $\theta$ 波, $\alpha$ 波が減少し，その後 $\delta$ 波が出現寸るというパ ターンは，鬼の耳の基部を圧しても，体位変換 による動物催眠でも起こるが，後者では after effect はない，一方の兔に針マスイを行ない， これと血液交叉循環した他の鬼にも，このパタ ーンが見られるのは，体液説 (Neuro-secretion) も考えられる証左の一つである (武重). しか しこの体液説ではどうして，特定のつぼが針マ スイに用いられるかの説明に困難を感じる（相 川)。またこの体液説に 重大な関係あるセロ卜 ニンにしても，中脳のまわりのノイロンに関係 ある部のあることは想像がっくが，これがマス イ誘発物質と断言するのはむずかしい。

最近アアメリカの J.J Bonica は中国の針マ スイ視察記録（JAMA229(10)）に，中国でも1015\%の手術に針マスイしか行なわれていないら しいと述べたのち，針マスイの研究は，米国の 医師がハリの手技に習熟した状態で豊富な臨床 例を集めた後でなければ見捨てるべきではない と言っている．針については 2,000 年の伝統の あるわが国ではもっと医師が針炎についての臨 床と基礎に関心をもち，この領域が硬直した西 洋医学に一つの新しい方向をもたらすことがで きるよう努力すべきものと考える. 最後に本シ ンポジウムの司会の医歯大池園教授の周到さに 敬意を表したい。

\section{“総合医 器展”印象記}

（株）市河思誠堂

市河鴻 -

4 年を周期として開かれる医学の祭典，第19 回日本医学会総会は, 去る 4 月 5 日から 3 日間,
シュワイッアー像をシンボルマークとし，「生 命への畏敬と医学の探究」をその標語として, 